\title{
Functioning Gonadotroph Adenoma with Secondary Hypersecretion of Testosterone
}

\author{
Annelie Kérékou Hodé1, Hubert Dédjan', Luphin Hodé2, Martial Agbokpanzo² \\ ${ }^{1}$ Service d'Endocrinologie, de Métabolisme et de Nutrition, CNHU-HKM, Cotonou, Bénin \\ ${ }^{2}$ Service de Traumatologie et d'Orthopédie, CNHU-HKM, Cotonou, Bénin \\ Email: kerekouannelie@yahoo.fr
}

How to cite this paper: Hodé, A.K. Dédjan, H., Hodé, L. and Agbokpanzo, M. (2020) Functioning Gonadotroph Adenoma with Secondary Hypersecretion of Testosterone. Open Journal of Endocrine and Metabolic Diseases, 10, 24-28.

https://doi.org/10.4236/ojemd.2020.102004

Received: January 29, 2020

Accepted: February 24, 2020

Published: February 27, 2020

Copyright $\odot 2020$ by author(s) and Scientific Research Publishing Inc. This work is licensed under the Creative Commons Attribution International License (CC BY 4.0).

http://creativecommons.org/licenses/by/4.0/

\begin{abstract}
Introduction: Gonadotroph adenomas are generally nonfunctioning. Hypersecretion of gonadotropins by gonadotroph adenomas rarely induced hypersecretion of testosterone. We report a case of functioning gonadotroph adenoma with secondary hypersecretion of testosterone. Medical Observation: A 25-year-old patient who having had a progressive and bilateral loss of visual acuity for two years. The ophtalmologist's examination concluded to bitemporal hemianopia. He had no other clinical manifestations of hyper or hypo hormonal secretion. The brain scan has revealed an intrasellar mass with suprasellar development that represses the optic chiasma and the carotids. The assessment carried out revealed an increase in FSH, LH and testosterone. The diagnosis of a functioning gonadotroph macroadenoma with secondary hypersecretion of testosterone was retained. Surgical excision of the adenoma was performed. Anatomo-pathological examination concluded to a pituitary adenoma. The patient showed an improvement in the right visual acuity and developed an adrenal corticotropic insufficiency substituted by hydrocortisone 20 $\mathrm{mg}$ per day. The postoperative hormonal profile revealed a normalization of FSH and testosterone. Conclusion: Functioning gonadotroph adenoma with secondary hypersecretion of testosterone is rare. The first-line treatment is surgical and allows an improvement of the cerebral tumor syndrome and the restoration of the gonadotropic function.
\end{abstract}

\section{Keywords}

Macroadenoma, Pituitary, Gonadotroph, Testosterone

\section{Introduction}

Gonadotroph adenomas are generally non-functional and represent more than 
$90 \%$ of non-functioning pituitary adenomas. Recent studies revealed that 20 to $25 \%$ of pituitary macro adenomas are functioning gonadotroph adenomas [1] [2] [3]. This hypersecretion of gonadotropins rarely induces hypersecretion of testosterone in humans because the secreted gonadotropins are often inactive. We report the medical observation of a case of functioning gonadotroph adenoma with secondary hypersecretion of testosterone.

\section{Medical Observation}

A 25-year-old patient hasn't had particular pathological history. He has no changes in libido or erectile dysfunction. He has had headaches since two years and a gradual, bilateral decline in visual acuity. Initially, this decrease in visual acuity was attributed to glaucomatous neuropathy. However, the worsening of visual acuity despite the anti-glaucomatous treatment required the advice of a second ophthalmologist. Clinical examination of the latter revealed a bitemporal hemianopsia but more pronounced in the left eye which was pre-blind. The rest of the clinical examination noted a patient in fairly good general condition, a weight of 73 kilos, a height of $1.7 \mathrm{~m}$ with a body mass index (BMI) at $25 \mathrm{~kg} / \mathrm{m}^{2}$, blood pressure at 110/80 $\mathrm{mmHg}$, the pulse at 60 beats/minute. There were no other clinical manifestations of hormonal hypo or hypo secretion. The brain scanner revealed an intrasellar mass of 64X57X46 mm with suprasellar extension compressing the optical, chiasma (Figure 1). Laboratory tests revealed: follicle-stimulating hormone (FSH) raised to $49.78 \mathrm{mIU} / \mathrm{ml}$ (1 to 5), Luteinizing hormone (LH) normal to $2.92 \mathrm{mUI} / \mathrm{ml}(1-8)$, the alpha subunit is not dosed, testosterone higher than $13.5 \mathrm{ng} / \mathrm{ml}$ (2.5 to 8.5 ), the normal thyroid stimulating hormone (TSH) at $0.83 \mu \mathrm{UI} / \mathrm{ml}$, the normal thyroid hormones (T4l at $0.98 \mathrm{ng} / \mathrm{dl}$ and T3l at $0.27 \mathrm{ng} / \mathrm{dl}$ ) normal prolactinemia at $17.29 \mathrm{ng} / \mathrm{ml}$, normal 8 -hour cortisol at $162.9 \mathrm{ng} / \mathrm{dl}$, blood sugar was normal at $0.98 \mathrm{~g} / \mathrm{l}$.

The diagnosis of a functioning gonadotroph macroadenoma with secondary hypersecretion of testosterone was retained. His surgical excision was carried out

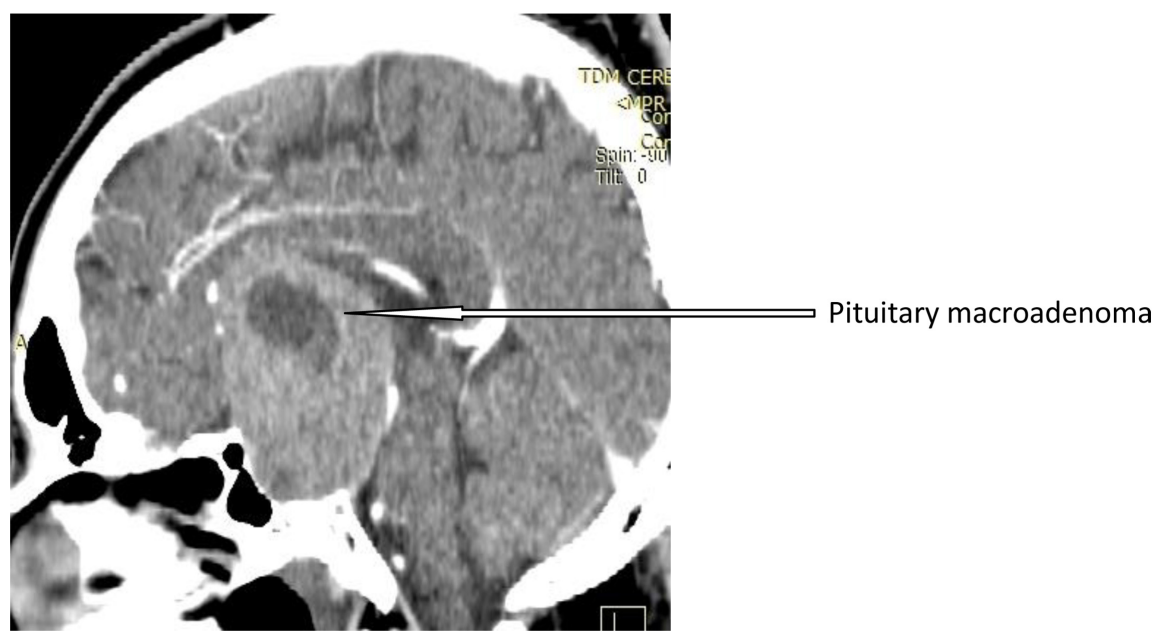

Figure 1. Pituitary macroadenoma. 
pterionally. The postoperative consequences are marked by the occurrence of corticotropic adrenal insufficiency substituted with hydrocortisone $20 \mathrm{mg} /$ day, a marked improvement in the vision of the right eye confirmed one month after surgery by ophthalmological examination.

An anatomopathological examination of the operating fragment identified a tumor proliferation of papillary architecture made with monomorphic nucleus in the rounded cells. The immunohistochemical study showed that adenomatous elements are marked by anti-LH antibodies (70\%), alpha unit (90\%) and FSH (90\%). There was no labeling with anti-prolactin antibodies, GH and ACTH. The M1B1 index is 3\%. The P53 index is 9/10 HPG.

The postoperative hormonal assessment noted the normalization of FSH and testosterone. A follow-up postoperative brain scan at 3 months, 6 months and 1 year was planned for follow-up.

\section{Discussion}

Functioning gonadotroph adenoma with secondary testosterone hypersecretion was rare because excess secreted gonadotropins are generally inactive. To our knowledge, four cases have been described today [4]. The age of our patient was lower than the age of these four patients, which varied from 45 to 61 years [4]. The clinical manifestations of functioning gonadotroph adenoma with secondary hypersecretion of testosterone were precocious puberty in children, an increase in the volume of the testes often greater than $25 \mathrm{ml}$ in adults and brain tumor syndrome [5]. The first two clinical manifestations were specific, but their presence was exceptional. The four patients described in the literature had not presented them [4]. It was the same for our patient. Cerebral tumor syndrome was frequent and constitutes the main circumstance of discovery since gonadotroph adenomas are often macro-adenomas [4]. Our patient presented with brain tumor syndrome as described in the other four study.

FSH and LH were elevated in all four patients while the increase in FSH was noted in our patient. Several authors have described the increase in FSH in all cases of functioning gonadotroph adenomas [2] [5] [6] [7] [8]. LH was found normal, low or increased by several authors in functioning gonadotroph adenomas [2] [7] [9].

The first-line treatment was surgical. It generally restores the function of the gonadotroph axis and gradually reduces the size of the testes. There was no recurrence in 2 to 5 years after surgery alone or in combination with radiotherapy [7] [8] [10] [11] [12] [13]. Radiotherapy can be used as an adjuvant therapy for incomplete excision or recurrence [14]. Medical treatment with dopaminergic agonists, somatostatin analogs, agonists or antagonists of gonadotropins releasing hormone could be used but these drugs have not proven to be effective and were therefore not recommended as first line [5]. In our patient, the surgery improved the visual acuity of the right eye and led to a drop in gonadotropins and testosterone. 


\section{Conclusion}

Functioning gonadotroph adenoma with secondary hypersecretion of testosterone was rare. Our patient was the fifth case described in the literature. The main reason for discovery was brain tumor syndrome. The first-line treatment was surgical and allowed an improvement in the cerebral tumor syndrome and the restoration of gonadotropic function.

\section{Conflicts of Interest}

The authors declare no conflicts of interest regarding the publication of this paper.

\section{References}

[1] Hirano, M., Wada-Hiraike, O., Miyamamoto, Y., et al. (2019) A Case of Functioning Gonadotroph Adenoma in a Reproductive Aged Woman. Endocrine Journal, 66, 653-656. https://doi.org/10.1507/endocrj.EJ19-0066

[2] Snyder, P.J. (1987) Gonadotroph Cell Pituitary Adenomas. Endocrinology and Metabolism Clinics of North America, 16, 755-764.

https://doi.org/10.1016/S0889-8529(18)30472-9

[3] Beckers, A., Stevenaert, A., Mashiter, K., et al. (1985) Follicle-Stimulating Hormone-Secreting Pituitary Adenoma. The Journal of Clinical Endocrinology \& Metabolism, 61, 525-528.https://doi.org/10.1210/jcem-61-3-525

[4] Chamoun, R., Layfield, L. and Couldwell, W.T. (2013) Gonadotroph Adenoma with Secondary Hypersecretion of Testosterone. World Neurosurg, 6, 900e7-900e11. https://doi.org/10.1016/j.wneu.2012.11.069

[5] Ntali, G., Capatina, C., Grossman, A., et al. (2014) Functioning Gonadotroph Adenomas. The Journal of Clinical Endocrinology \& Metabolism, 99, 4423-4433. https://doi.org/10.1210/jc.2014-2362

[6] Pigny, P., Henric, B., Lahlou, N., et al. (1996) A Gonadotroph Adenoma with a High Proportion of Basic FSH Isohormones by Chromatofocusing. The Journal of Clinical Endocrinology \& Metabolism, 81, 2407-2408.

[7] Heseltine, D., White, M.C., Kendall-Taylor, P., et al. (1989) Testicular Enlargement and Elevated Serum Inhibin Concentrations Occur in Patients with Pituitary Macroadenomas Secreting Follicle-Stimulating Hormone. Clinical Endocrinology, 31, 411-423. https://doi.org/10.1111/j.1365-2265.1989.tb01265.x

[8] Dahlqvist, P., Koskinen, L.O., Brännström, T., et al. (2010) Testicular Enlargement in a Patient with a FSH-Secreting Pituitary Adenoma. Endocrine, 37, 289-293. https://doi.org/10.1007/s12020-009-9302-z

[9] Clemente, M., Caracseghi, F., Gussinyer, M., et al. (2011) Macroorchidism and Panhypopituitarism: Two Different Forms of Presentation of FSH-Secreting Pituitary Adenomas in Adolescence. Hormone Research in Paediatrics, 75, 225-230. https://doi.org/10.1159/000322211

[10] Murakami, M., Higashitsuji, H., Yoshinaga, K., et al. (2004) Management of Ovarian Hyperstimulation Due to Follicle-Stimulating Hormone-Secreting Gonadotroph Adenoma. Obstetrics and Gynecology, 111, 1297-1300. https://doi.org/10.1111/j.1471-0528.2004.00409.x

[11] Knoepfelmacher, M., Danilovic, D.L., Rosa Nasser, R.H., et al. (2006) Effectiveness of Treating Ovarian Hyperstimulation Syndrome with Cabergoline in Two Patients 
with Gonadotropin-Producing Pituitary Adenomas. Fertility and Sterilty, 86, 719e15719e18. https://doi.org/10.1016/j.fertnstert.2006.01.055

[12] Sicilia, V., Earle, J.,Mezitis, S.G. et al. (2006) Multiple Ovarian Cyst and Oligomenorrhea as the Initial Manifestations of a Gonadotropin-Secreting Pituitary Macroadenomas. Endocrine Practice, 12, 417-421.https://doi.org/10.4158/EP.12.4.417

[13] Tashiro, H., Katabuchi, H., Ohtake, H. et al. (2000) An Immunohistochimical and Ultrastructural Study of a Follicle-Stimulating Hormone-Secreting Gonadotroph Adenoma Occurring in a 10-Year-Old Girl. Medical Electron Microscopy, 33, 25-33. https://doi.org/10.1007/s007950000004

[14] Varlamov, E.V., McCartney, S. and Fleseriu, M. (2019) Functioning Pituitary Adenomas-Current Treatment Options and Emerging Medical Therapies. European Endocrinology, 15, 30-40. https://doi.org/10.17925/EE.2019.15.1.30 